\title{
Identification of Mycoplasma Muris Isolated from Vaginal Samples of NIIH Mice
}

\author{
Mohammad Reza Zinatizadeh ${ }^{1}$, Fatemeh Abedini ${ }^{* 2}$, Mostafa Jafarpour ${ }^{3}$, Zahra \\ Masoumalinejad $^{4}$
}

\author{
1. Department of Genetics, Faculty of Science, Tonekabon Branch, Islamic Azad University, Mazandaran, Iran \\ 2. Department of Animal Breeding, Razi Vaccine and Serum Research Institute, Karaj, Iran \\ 3. Department of Microbiology, Faculty of Science, Tonekabon Branch, Islamic Azad University, Mazandaran, Iran \\ 4. Department of Microbiology, Sirjan Branch, Islamic Azad University, Sirjan, Iran
}

\section{KEYWORDS}

\begin{tabular}{c} 
Mycoplasma muris \\
PCR \\
New strain \\
16S rRNA sequences \\
NIH Mice \\
\hline Article Info
\end{tabular}

Received 2019/02/01;

Accepted 2019/03/12;

Published Online 2019

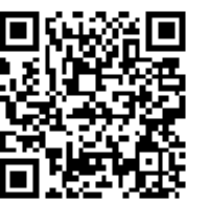

\begin{abstract}
Mycoplasma muris (M.M) is a small pathogenic bacterium that lives in the female mouse genital tract. Mycoplasma muris may have harmful effects on the reproductive health of female. This research was performed to optimize the detection of M. muris in NIH mice in the Department of Animal Breeding, Razi Vaccine and Research Institute, Iran. In this cross-sectional study, 29 vaginal samples of NIH mice were selected through simple random sampling. For detection of the mycoplasma, the vaginal tissue removal of samples was done. First, samples were crushed using mortar and pestle with PBS 1ml, then were cultured in the PPLO broth and incubated at $37^{\circ} \mathrm{C}$ for $24 \mathrm{~h}$, they were passed through $0.45 \mu \mathrm{m}$ pore-size filters and inoculated into specific PPLO broth and agar media for 3-4 weeks. In the next section, the PCR test was used with primers of $16 \mathrm{~S}$ rRNA gene of M. muris. From 29 tested samples, 17.24\% samples were positive for $M$. muris by PCR method, while $35.93 \%$ cultures showed positive. The phylogenetic analysis indicated a new strain of M. muris. The results of culture and PCR methods displayed the contamination in NIH mice. Therefore, Therefore, more researches are needed regarding the presence of mycoplasma for treatment and clinical signs.
\end{abstract}

Corresponding Information: Agricultural Research, Education and Extension Organization (AREEO), Research \& Development Department,Razi Vaccine and Serum Research Institute, E-mail: ftmhabedinii@gmail.com

Copyright ( $\odot$ 2019. This is an open-access article distributed under the terms of the Creative Commons Attribution-noncommercial 4.0 International License which permits copy and redistribute the material just in noncommercial usages, provided the original work is properly cited.

\section{Introduction}

Mycoplasmas were first isolated from rodents almost 80 years ago, and exist generally in all creatures $(1,2)$ and are recognized via various diseases, including pneumonia, arthritis, meningitis and chronic urogenital tract diseases (3). They are the members of the class Mollicutes with more than 120 species; $23-40 \%$ of the $\mathrm{G}+\mathrm{C}$ content, the range of a genome size is about $600-1350 \mathrm{~kb}$, they require cholesterol for growth and cause the diseases in humans and animals (4). Mycoplasmas are substantial and chronic bacterial pathogens for humans and animals that often colonize in the respiratory and genitourinary tracts (5).

A mycoplasma infection typically induces persistence of subclinical infections in mice colonies. Recent surveys have demonstrated that approximately $60 \%$ of all the conventional laboratory rat and mice colonies are infected with one or more mycoplasmas (6). The microorganisms lack a cell wall and are highly polymorphic, which makes them resistant to antimicrobials that are effective on the cell structure, such as penicillin. These bacteria are probably derived from Gram-positive bacteria and their phylogeny is similar to Clostridium, however, the mycoplasma bacterium is Gram-negative (7).

The diagnosis of Mycoplasma species based on modern techniques requires a relatively large amount of time to be identified (8). The 16S rRNA gene sequencing plays an important role to identify 
isolates of bacteria particularly rare bacteria, slowgrowing bacteria, and the discovery of novel bacteria (9).

M. muris is a small pathogenic bacterium that lives in the genital tracts of mice. There is a specific relationship between $M$. muris and U. urealyticum clusters, which was first reported in 1983, and the mycoplasma infection is extremely rare among the mice (10). At present, there is no sufficient information regarding $M$. muris pathological state (11). The aim of this research study was to set up and optimize specific PCR method for detection of Mycoplasma muris in NIH mice.

\section{Materials and Methods Animals}

All NIH mice were kept under standard conditions in Department of Animal Breeding Razi Vaccine and Research Institute. The protocol was approved by the animal care committee of Razi Vaccine and Serum Research Institute (MED.0309.QGL) that was performed on 29 vaginal samples of NIH mice from the Animal Breeding Center Razi Institute.

\section{Growth conditions}

In this cross-sectional study, 29 Vaginal Samples of NIH mice were selected through simple random sampling. For detection of the mycoplasma, the vaginal tissue removal of samples was done and crushed using mortar and pestle with PBS $1 \mathrm{ml}$. Samples were placed in the PPLO broth solution $(3 \mathrm{ml})$ at $37^{\circ} \mathrm{C}$ for $24 \mathrm{~h} .15 \%$ of hours serum, thallium acetate $(1: 4000)$, penicillin (1000IU/ml), $0.0125 \% \quad \beta$-Nicotinamide adenine dinucleotide (NAD) and $0.0125 \%$ cysteine hydrochloride were added into PPLO broth and PPLO agar medium (BBL, Becton Dickinson and company, Cockeyville, Sparks, MD, USA) as necessary requirements for M. muri. After one day, all samples were filtered with CHROMAFIL ${ }^{\circledR}$ CA-45/25S, then were transferred into the new PPLO broth (1ml) and kept in an incubator at $37^{\circ} \mathrm{C}$ under $5 \% \mathrm{CO} 2$ for 3-4 weeks. $0.5 \mathrm{ml}$ of samples were transferred to PPLO agar media and checked for typical mycoplasma colonies.

\section{DNA extraction}

DNA extraction was accomplished using phenol-chloroform method (12). Briefly, $1 \mathrm{ml}$ of each sample were centrifuged at $13000 \mathrm{rpm}$ for 15 min. The supernatant fluid was discarded, PBS $(150 \mu l)$ and Lysozyme $(100 \mu l)$ were added, then the tubes were kept on the hot plate at $37^{\circ} \mathrm{C}$ for 30 $40 \mathrm{~min}$. All of the samples with Lysis buffer (Tris$\mathrm{HCl} 50 \mathrm{mM} \mathrm{pH}=8$, SDS 1\%, NaCl 100mM, EDTA $50 \mathrm{mM}$, proteinase $\mathrm{K} 20 \mu \mathrm{l}$ to $100 \mu \mathrm{l}$ ) were shifted to the tubes and placed in a $56^{\circ} \mathrm{C}$ bath for $4 \mathrm{~h}$. Then $200 \mu \mathrm{l}$ saturated phenol was added and centrifugation was done (13000 rpm or $15700 \mathrm{~g}$ ) for 15 min while supernatant was transferred to a new microtube and mixed, phenol /chloroform (1:1) was added with an equal volume. After centrifugation at $13000 \mathrm{rpm}$ for $15 \mathrm{~min}$, the aqueous phase was transferred and added to equal volume of pure chloroform. Samples were centrifuged (13000 rpm) for $15 \mathrm{~min}$. Upper phase was mixed with $1 / 10$ volume of acetate sodium solution $3 \mathrm{M}$ and were precipitated with 2 times volume of cool ethanol (it was kept at $-20^{\circ} \mathrm{C}$ for 20 $\mathrm{min}$ and centrifuged for $15 \mathrm{~min}$ at $13000 \mathrm{rpm}$ ). The next,

discarded ETOH and drying tubes then added $50 \mu \mathrm{l}$ distilled water to them.

\section{Amplification with specific primers (PCR)}

In this study, published primers were used for the specific diagnosis of genus and species of $M$. muris. The primer of Mycoplasma genus is as follows: M1F: 5'-GCTGCGGTGAATACGTTCT3', M3R: 5'-TCCCCACGTTCTCGTAGGG-3' (13). Specific amplification primers of M. muris were used, MMF: 5'TTAAAGTTCCGTTTGGAACG-3' and MMR: 5'ATCATTTCCTATTCCTACCA-3' that described by Van Kuppeveld et al (6). The PCR master mix (Biosystems Company, 2x PCRBIO Taq Mix Red) was prepared in a total volume of $25 \mu \mathrm{l}$ per sample, containing $(12.5 \mu \mathrm{l}$ of $2 \mathrm{X}$ PCR Master Mix, $1 \mu \mathrm{l}+1 \mu \mathrm{l}$ primer $10 \mu \mathrm{M}, 3 \mu \mathrm{l}$ DNA template, and $7.5 \mu$ l water). The PCR reaction was conducted in a master cycler (Eppendorf, Germany) as follows: for detection of genus: $7.5 \mathrm{~min}$ at $94^{\circ} \mathrm{C}$, followed by 30 cycles of $30 \mathrm{~s}$ at $94^{\circ} \mathrm{C}, 30 \mathrm{~s}$ at $56^{\circ} \mathrm{C}$ and $1 \mathrm{~min}$ at $72^{\circ} \mathrm{C}$, with a final extension cycle of $5 \mathrm{~min}$ at $72^{\circ} \mathrm{C}$. For 
detection of mycoplasma muris: $10 \mathrm{~min}$ at $94^{\circ} \mathrm{C}$, followed by 35 cycles of $30 \mathrm{sec}$ at $94^{\circ} \mathrm{C}, 1 \mathrm{~min}$ at $54^{\circ} \mathrm{C}$ and $30 \mathrm{sec}$ at $72^{\circ} \mathrm{C}$, with a final extension cycle of $7 \mathrm{~min}$ at $72^{\circ} \mathrm{C}$.

\section{PCR and Phylogenic Analysis}

A $10 \mu 1$ aliquot of each PCR products was mixed with $2 \mu 1$ loading buffer (6X) and separated using electrophoresis (in $1.7 \%$ agarose gel 1xTris-acetic acid-EDTA (TAE) buffer) with $0.5 \mu \mathrm{l} / \mathrm{ml}$ SYBR Safe (100 volts for 1 hour) and UVtransillumination. Positive samples of the PCR products were purified from agarose gel (High pure PCR product purification Kit, Roche) and sequenced by Bioneer Company, Korea. All sequences were analyzed by multiple sequence alignments and phylogenetic analysis using Clustal Omega

(http://www.ebi.ac.uk/Tools/msa/clustalo/).

\section{RESULTS}

\section{Isolation of mycoplasma}

Vaginal samples obtained from 29 NIH mice and were grown on PPLO broth medium at $37^{\circ} \mathrm{C}$ under aerobic conditions. First, colonies of the organisms were detected, then the incubation was conducted in the aerobic condition of broth cultures at $37^{\circ} \mathrm{C}$ for 3-4 weeks. Each isolate was purified by standard filtration. Some samples showed the growth on PPLO agar plates after 7 days of incubation and colonies were observed.

\section{Bacteriology}

Bacterial growth was observed in 11 samples out of 29 (35.93\%), in the PPLO broth and PPLO agar The Mycoplasma genus PCR (MGPCR) and Mycoplasma species PCR (MMPCR) produced 163 bp amplicons (12 samples out of the 29, $41.37 \%$ ) and $236 \mathrm{bp}$ amplicons (5 samples out of $29,17.24 \%$ ) which are displayed in figure 1 and figure 2 respectively. The full results are presented in Figure 3 and Table 1.

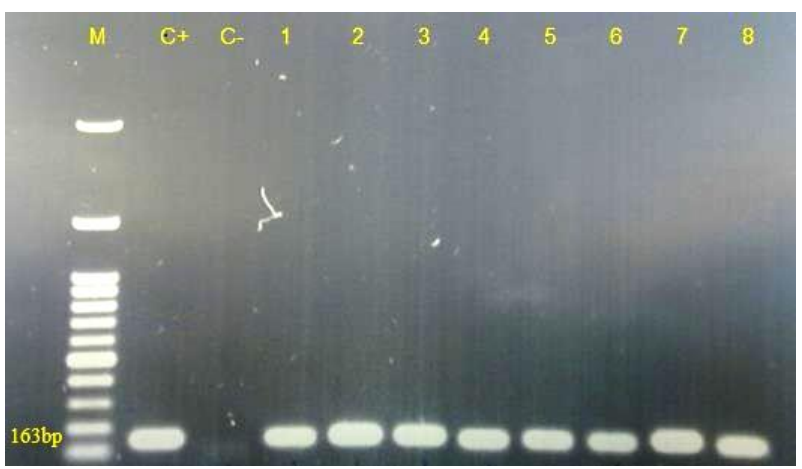

Fig 1. Mycoplasma genus PCR: PCR electrophoresis analysis in $1.7 \%$ gel agarose. M: Marker (100bp DNA ladder). Lane C+: Positive control (163bp band, Mycoplasma genus, NCTC 10123). Lane C-: Negative control (uncultured PPLO broth) and Lane 1-8: the isolated Mycoplasma.

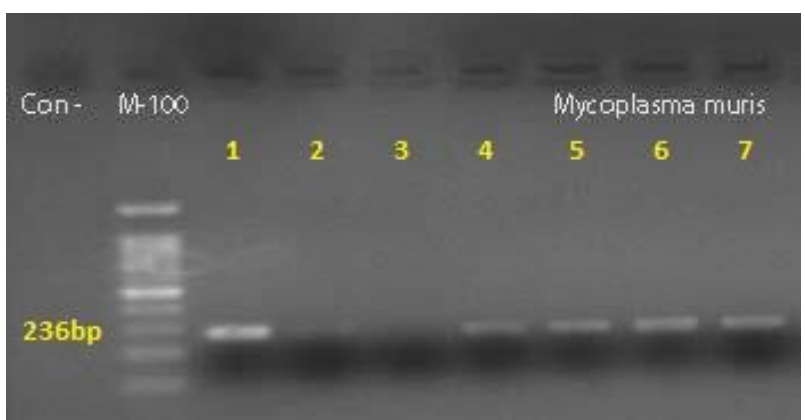

Fig 2. $M$. muris PCR: PCR electrophoresis analysis in $1.7 \%$ gel agarose.

M: Marker (100bp DNA ladder). Lane C-: Negative control (uncultured PPLO broth) and Lanes 1, 4-7: Positive results (236bp). Lanes 2, 3: Negative results.

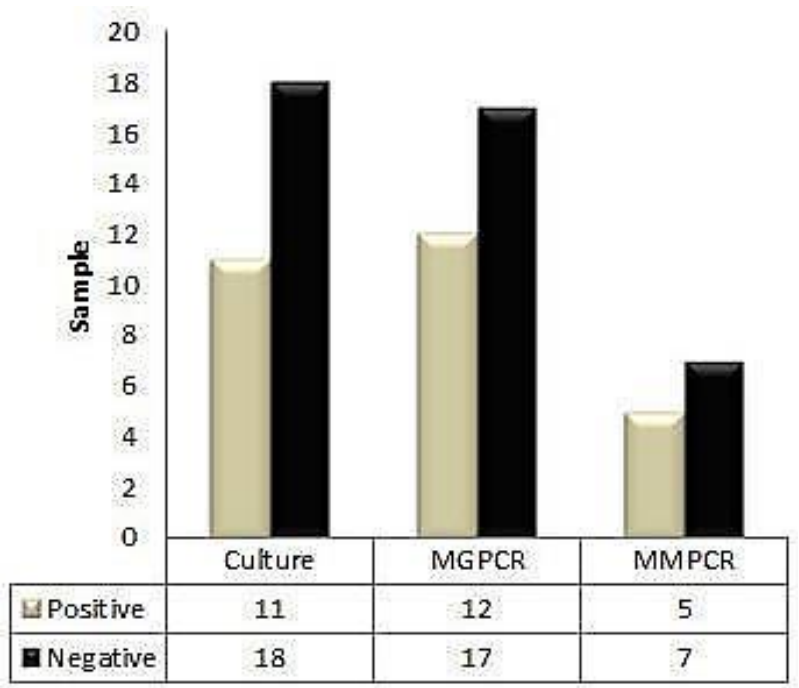

Fig 3. Sensitivity of the methods used for the diagnosis of M. muris in mice 
Table 1. The results of the culture and PCR methods in the vaginal samples

\begin{tabular}{ccc}
\hline Tests & Result & Total \\
\hline Culture & Positive & $(35.93 \%)$ \\
& Negative & $(62.06 \%)$ \\
\hline & Positive & $(41.37 \%)$ \\
\hline MGPCR & Negative & $(58.62 \%)$ \\
\hline MMPCR & Positive & $(17.24 \%)$ \\
\hline & Negative & $(24.13 \%)$ \\
\hline
\end{tabular}

\section{Calculation (Coefficient, Sensitivity, Specificity)}

In table 2, the results have indicated that the sensitivity of PCR method is more than $80 \%$ to detect the Mycoplasma and the specificity of PCR assay is $94.44 \%$ (14).

Table 2. Distribution of samples for culture and the results of Mycoplasma-PCR methods (coefficient, sensitivity, specificity)

\begin{tabular}{ccc}
$\begin{array}{c}\text { No. } \\
\text { Sample }\end{array}$ & Culture & MGPCR \\
\hline 10 & + & + \\
16 & - & - \\
2 & - & + \\
1 & + & -
\end{tabular}

29Total

$$
\begin{gathered}
\text { Coefficient }=\frac{(\text { MGPCR positive,Cululture positive })+(\text { MGPCR Negative,Cululture Negative })}{\text { Total }} \times 100 \\
\frac{26}{29} \times 100=\mathbf{8 9 . 6 5 \%}
\end{gathered}
$$

Sensitivity $=\frac{(\text { MGPCR positive }, \text { Cululture positive })-(\text { MGPCR Negative, } \text { Cululture positive })}{(\text { MGPCR positive,Cululture positive })+(\text { MG PCR Negative, Cululture positive })} \times 100$

$$
\frac{9}{11} \times 100=\mathbf{8 1 . 8 1} \%
$$

$$
\begin{gathered}
\text { Specificity }=\frac{(\text { MGPCR Negative }, \text { Cululture Negative })+(\text { MGPCR Negative }, \text { Cululture positive })}{(\text { MGPCR Negative,Cululture Negative })+(\text { MGPCR positive }, \text { Cululture Negative })} \times 100 \\
\frac{17}{18} \times 100=\mathbf{9 4 . 4 4} \%
\end{gathered}
$$

\section{Phylogenetic Analysis}

Phylogenetic analysis was done by the obtained data from the sequences of the M. muris isolates and were published in GenBank (Fig.4). Our sequence data have been submitted to GenBank and assigned the accession number of KX792083 for a new strain of $M$. muris (MYMORazi) from Iran. The accession numbers of the nucleotide sequence for other $M$. muris strains (16s rRNAs) in GenBank, that were applied in this study are as follows: NR-044664.2 (strain RIII-4), AY753215.1, and D89507.1. In the phylogenetic analysis, MYMORazi, AY753215.1, and D89507.1 were joined together in a monophyletic clade that was most closely related to the Mycoplasma muris. As expected, as expected, AY753215.1 and D89507.1 are located in the MYMORazi cluster. 


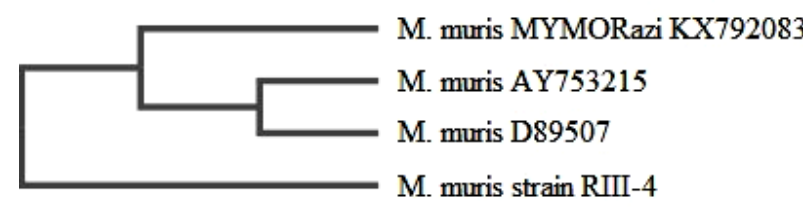

Fig 4. Phylogenetic analysis of Mycoplasma muris 16s rRNA. Phylogenetic relationships of MYMORazi with other related strains. The bar indicates 5\% sequence divergence.

\section{Discussion}

In this study, $M$. muris was detected from vaginal samples of NIH mice using culture and PCR methods in Razi Vaccine and Serum Research Institute, Alborz, Iran. In previous studies, SP-4 medium and strict anaerobic conditions were used for M. muris diagnosis while in the present study, PPLO medium under aerobic condition was applied (11). The presence of bacterial pollution, PCR assay can be used on mycoplasma growth in the culture (24h of Mycoplasma enrichment for growth in the culture medium). (15).

PCR is routinely used as a molecular detection method in many laboratories, because of its high sensitivity (6). The 16S rRNA gene has been shown as a noteworthy marker for species identification using different molecular biological techniques such as denaturing gradient gel electrophoresis (DGGE), restriction analysis, pulsed-field gel electrophoresis (PFGE), random amplified polymorphic DNA (RAPD) and gene sequencing (16-20). Numerous bacterial 16S rRNA sequences have been consigned in databases in GenBank or (EMBL) for nucleotide sequences (21).

Based on the phylogeny analysis of the $16 \mathrm{~S}$ rRNA gene, $M$. muris is the common and ancestral cluster of the pneumonia group (10), in fact, $M$. muris 16S rRNA gene sequence clusters with the other previously identified mycoplasmas on a branch related to the pneumoniae group of Mycoplasma genus (10). The pneumoniae group comprises three distinct clusters represented by $M$. pneumoniae, $M$. muris, and Ureaplasma urealyticum.

Three agents cause main infections of the genitourinary tract in the mice. Leptospira interrogans serovar ballum (LISB) leads to renal infection and has been reported in laboratory mice. Mycoplasma muris has been isolated from the vaginas of mice and has occurred in the female genital tract infections with M. pulmonis.

Amplification and sequencing of the $M$. muris 16S rRNA gene were obtained according to Van Kuppeveld' study. (6). Our data demonstrated that $17.24 \%$ of samples were positive by PCR method with the Mycoplasma species primer. Sequencing of the 16s rRNA has shown that the sequence analysis of the gene is a valuable tool for tracing $M$. muris isolated from the NIH mice.

In this study, one of the samples was positive for PCR method but showed negative in culture. Therefore, this study indicates that contamination level is close to the results of PCR test compared to culture method. The sequences were compared in GenBank using BLASTN program and aligned by Clustal Omega software. Our results displayed that MYMORazi strain (accession number KX792083) was phylogenetically related to the members of the muris species with the $98 \%$ similarity sequence. The phylogenic relationships can be determined between $M$. muris strains as a new strain. The phylogenic confirms a new strain for epidemiological aims and the phylogenic studies are essential to understanding the relationships between strains.

\section{Conclusion}

Studies have demonstrated that $M$. muris is an emerging sexually transmitted infection. Additional more researches are needed regarding their pathogenicity and resistance for clinical detection and treatment. Clinical detection and pathogenicity for $M$. muris infection should be considered.

\section{Acknowledgments}

We thank all the staff of the Mycoplasma Reference Laboratory, Animal Breeding Center, Razi Vaccine, and Serum Research Institute, Karaj, Iran. This study was supported by a grant of Research and Development Deputy of Razi Institute. The authors declare no conflict of interest. 


\section{References}

1. Nelson JB. Infectious catarrh of mice: ii. the detection and isolation of coccobacilliform bodies. The Journal of experimental medicine. 1937; 65(6): 843-849.

2. Razin S, Yogev D, Naot Y. Molecular biology and pathogenicity of mycoplasmas. Microbiology and Molecular Biology Reviews. 1998; 62(4): 1094-1156.

3. Waites KB, Katz B, Schelonka RL. Mycoplasmas and ureaplasmas as neonatal pathogens. Clinical microbiology reviews. 2005;18(4): 757-789.

4. Razin S. Molecular biology and genetics of mycoplasmas (Mollicutes). Microbiological reviews. 1985 ; 49(4): 419-455.

5. Simmons WL, Dybvig K. Mycoplasma biofilms ex vivo and in vivo. FEMS microbiology letters. 2009; 295(1): 77-81.

6. Van Kuppeveld FJ, Van der Logt JT, Angulo AF, Van Zoest MJ, Quint WG, Niesters HG, Galama JM, Melchers WJ. Genus-and species-specific identification of mycoplasmas by $16 \mathrm{~S}$ rRNA amplification. Applied and environmental microbiology. 1992; 58(8): 2606-2615.

7. Taylor-Robinson D, Jensen JS. Mycoplasma genitalium: from Chrysalis to multicolored butterfly. Clinical Microbiology Reviews. 2011; 24(3): 498-514.

8. Yamamoto M, Asahara M, Tamura T, Matsumura M, Hayashimoto N, Makimura K. Rapid identification of Mycoplasma pulmonis isolated from laboratory mice and rats using matrix-assisted laser desorption ionization timeof-flight mass spectrometry. Journal of Veterinary Medical Science. 2012; 74(8): 10831086.

9. Woo PC, Lau SK, Teng JL, Tse H, Yuen KY. Then and now: use of $16 \mathrm{~S}$ rDNA gene sequencing for bacterial identification and discovery of novel bacteria in clinical microbiology laboratories. Clinical Microbiology and Infection. 2008; 14(10): 908934.

10. Weisburg WG, Tully JG, Rose DL, Petzel JP, Oyaizu H, Yang D, Mandelco L, Sechrest J, Lawrence TG, Van Etten J. A phylogenetic analysis of the mycoplasmas: basis for their classification. Journal of bacteriology. 1989; 171(12): 6455-6467.

11. McGarrity GJ, Rose DL, Kwiatkowski V, Dion AS, Phillips DM, Tully JG. Mycoplasma muris, a new species from laboratory mice. International Journal of Systematic and Evolutionary Microbiology. 1983; 33(2): 350-355.

12. Pourbakhsh SA, Shokri GR, Banani M, Elhamnia F, Ashtari AB. Detection of Mycoplasma synoviae infection in broiler breeder farms of Tehran province using PCR and culture methods. Archives of Razi Institute. 2010; 65(2): 75-81.

13. Kojima A, Takahashi T, Kijima M, Ogikubo Y, Nishimura M, Nishimura S, Harasawa R, Tamura Y. Detection ofMycoplasmain Avian Live Virus Vaccines by Polymerase Chain Reaction. Biologicals. 1997; 25(4): 365-371.

14. Florkowski CM. Sensitivity, specificity, receiver-operating characteristic (ROC) curves and likelihood ratios: communicating the performance of diagnostic tests. Clin Biochem Rev. 2008; 29(1): 83-87.

15. Nicholas R, Ayling R, McAuliffe L. Mycoplasma diseases of ruminants. USA. CABI; 2008; 1-14.

16. McAuliffe L, Ellis RJ, Lawes JR, Ayling RD, Nicholas RA. 16S rDNA PCR and denaturing gradient gel electrophoresis; a single generic test for detecting and differentiating Mycoplasma species. Journal of Medical Microbiology. 2005; 54(8): 731-739.

17. Stakenborg T, Vicca J, Butaye P, Maes D, De Baere T, Verhelst R, Peeters J, de Kruif A, Haesebrouck F, Vaneechoutte M. Evaluation of amplified rDNA restriction analysis (ARDRA) for the identification of Mycoplasma species. BMC infectious diseases. 2005; 5(1): 1-10.

18. Marois C, Dufour-Gesbert F, Kempf I. Comparison of pulsed-field gel electrophoresis with random amplified polymorphic DNA for typing of Mycoplasma synoviae. Veterinary microbiology. 2001; 79(1): 1-9. 
19. Gray LD, Ketring KL, Tang YW. Clinical use of 16S rRNA gene sequencing to identify Mycoplasma felis and M. gateae associated with feline ulcerative keratitis. Journal of clinical microbiology. 2005; 43(7): 3431-3434.

20. Clarridge JE. Impact of $16 \mathrm{~S}$ rRNA gene sequence analysis for identification of bacteria on clinical microbiology and infectious diseases. Clinical microbiology reviews. 2004; 17(4): 840-862.

21. Pettersson B, Tully JG, Bölske G, Johansson KE. Updated phylogenetic description of the Mycoplasma hominis cluster (Weisburg et al. 1989) based on 16S rDNA sequences. International journal of systematic and evolutionary microbiology. 2000; 50(1): 291-301.

\section{How to cite this article:}

Zinatizadeh M R, Abedini F, Jafarpour M, Masoumalinejad Z. Identification of Mycoplasma Muris Isolated from Vaginal Samples of NIH Mice . Mod Med Lab J. 2019; 2 (1) :100-106 